\title{
Geriatric Intoxication in the Poison Control Center of Ain Shams University Hospitals, Egypt
}

\author{
Walaa G. Abdelhamid", Maha M. Wahdan ${ }^{2 *}$, Hanan M. Abdel Wahab ${ }^{3}$ \\ ${ }^{1}$ Forensic Medicine and Clinical Toxicology Department, Faculty of Medicine, Ain Shams University. \\ ${ }^{2}$ Community Medicine, Environmental, and Occupational medicine Department, Faculty of Medicine, \\ Ain Shams University. \\ ${ }^{3}$ Clinical Toxicology, Poison Control Center, Ain Shams University Hospitals.
}

\begin{abstract}
:
Background: The incidence of toxicity is increasing among the elderly. Presentation of poisoning may be delayed with atypical symptoms and signs and high mortality rates. Objectives: This study aimed to evaluate the epidemiological pattern of poisoning in the elderly Egyptian population and assess the severity of intoxication using poisoning severity score (PSS). Methods: A retrospective observational design was used for this study. All patients aged 60 years and older with acute poisoning who attended to the emergency department of Poison Control Center of Ain Shams University Hospitals (PCC-ASUH) during 2019 were included in the study. Results: Two hundred and fifty geriatric patients with acute poisoning attended to PCC-ASUH. Male patients outnumbered female patients $(58.8 \%$ versus $41.2 \%$, respectively). Most poisoning episodes were suicidal (44.8\%), followed by accidental intoxication (40.4\%). Antipsychotics were the commonest agents responsible for suicidal poisonings $(17 \%)$. Poisoning severity score was minor in 131 patients $(52.4 \%)$, moderate in 37 patients $(14.8 \%)$, and severe in 32 patients (12.8\%). Seven patients (2.8\%) died. Endotracheal intubation and mechanical ventilation were needed in 17 patients $(6.8 \%)$ and 4 patients $(1.6 \%)$ underwent hemodialysis. Conclusion: Attempting suicide was the commonest mode of poisoning in the elderly, mostly caused by antipsychotics, followed by accidental poisoning. Several variables could worsen PSS of the poisoned elderly like the manner of poisoning and presence of co-morbidities. Therefore, it is recommended to implement suicide prevention programs for the elderly and public awareness to reduce poisoning in this age group.
\end{abstract}

Keywords: Geriatric; Intoxication; Pattern; Poisoning severity score.

\section{Introduction:}

Over the past few years, the world's population has experienced tremendous growth in the proportion of elderly, defined as people aged 60 years and above. The geriatric population increased from $9.2 \%$ in 1990 to $11.7 \%$ in 2013 . By the year 2050 , it will represent $20 \%$ (315 million) of the total population which explains the possibility of increasing the incidence of toxicity in this age group. ${ }^{(1)}$
In Egypt, gradual increase in the percentages of the elderly population has been reported from $5.75 \%$ in 1996 to $6.27 \%$ in 2006, with an expected rise to $9.2 \%$ in 2021 and $20.8 \%$ in 2050 . Thus, the elderly are expected to reach 26.8 million by 2050 which resembles a full nation in some parts of the world. ${ }^{(2)}$

Geriatric patients represent about $2.3 \%$ of poisoning cases. Although they comprise a minority in poisoning events, the

*Corresponding author: drmaha_wahdan@med.asu.edu.eg

(c) (1) This article is an open access article distributed under the terms and conditions of the Creative Commons Attribution (CC BY) license (http://creativecommons.org/licenses/by/4.0/) 
dangerous consequences of intentional and unintentional poisoning in this age group should not be neglected. ${ }^{(3)}$

Compared to younger patients, the elderly have specific characteristics as unclear atypical complaints, difficult triage, more frequent hospital admissions, increased resources utilization, and finally a higher rate of adverse health outcomes. ${ }^{(4)}$

There are many factors responsible for intentional poisoning in the elderly such as loss of independence, depression, death of a spouse, and retirement. ${ }^{(5)}$ In addition, agerelated alteration in pharmacokinetics and pharmacodynamics, increased incidence of polypharmacy for chronic illness with increased potential for drug interactions, cognitive dysfunction, poor eyesight, and improper administration of medications are contributing factors to unintentional poisoning. ${ }^{(6)}$

Therefore, elderly patients account for most hospital and intensive care unit admissions with higher mortality rate compared to other age groups. This age group represented $26.78 \%$ out of the total poisoning related fatalities recorded by the American Association of Poison Control Centers (AAPCC) National Poison Data System (NPDS) for 2017. This warrants the attention to the risk factors and prognostic criteria of geriatric poisoning. ${ }^{(6)}$
We conducted this study to evaluate the epidemiological pattern of acute poisoning in elderly patients presented to Poison Control Center of Ain Shams University Hospitals (PCC-ASUH) during the period from $1^{\text {st }}$ of January 2019 to $31^{\text {st }}$ of December 2019 and assess the severity of intoxication using poisoning severity score (PSS).

\section{Methods:}

Study Design: A hospital-based retrospective observational study was performed.

Study setting: The Poison Control Center of Ain Shams University Hospitals (PCC$A S U H)$ is the major poison control center in Egypt; it is located in Cairo and has been in operation 24 hours a day since its establishment in 1981 as the first one of its kind in the Middle East. It is not only a tertiary teaching medical center, but also a referral center for the treatment of any poisoning cases received from all Egypt governorates.

Study time: The study was conducted on patients' medical records who attended to the Poison Control Center of Ain Shams University Hospitals (PCC-ASUH) in the period from $1^{\text {st }}$ of January 2019 to $31^{\text {st }}$ of December 2019.

Study population: All the patients aged 60 years and older presented to the emergency 
department (ED) of the Poison Control Center of Ain Shams University Hospitals (PCC-ASUH) with a history of toxic exposure were included in this study, even asymptomatic patients who were directly discharged from the ED. The diagnosis was established by history, physical examination, routine, and toxicology laboratory evaluation following the PCCASUH protocols.

Sampling method and sample size: Purposive sampling was used to include medical records for only patients aged 60 years and older. Using PASS 11 program, reviewing data and results from the previous study by Karbakhsh and Zandi., 2008 showed that the use of poisoning severity score in the evaluation of poisoning severity revealed that $17 \%$ of cases had severe poisoning. Accordingly, a sample size of at least 220 medical records is needed.

Study tools: Data were extracted using extraction sheet from the center's electronic database and medical records where patient lists in the electronic medical records were regularly and systematically searched during the study period to ensure the inclusion of all eligible patients.

Poisoning Severity Score (PSS) of the European Association of Poisons Centers and Clinical Toxicologists (EAPCCT) was used to grade the severity of poisoning at the time of initial inquiry as indicated by the patient's clinical features; it is intended to be an overall evaluation of the case, taking into account the most severe clinical features. The score has five grades: PSS (0): none, no symptoms or signs related to poisoning, PSS (1): mild, transient, and spontaneously resolving symptoms or signs, PSS (2): moderate, pronounced, or prolonged symptoms or signs; PSS (3): severe or life-threatening symptoms or signs, and PSS (4): fatal / death). ${ }^{\text {(7) }}$

Study variables: The collected data included demographics, type of toxic agent(s), manner of poisoning, route of exposure, the time interval between exposure and arrival to the PCC-ASUH (delay time), presence of co-ingestion of other drugs or agents, pre-hospital management before presentation to PCCASUH, medical comorbidities, special habits of medical importance as smoking or substance abuse, different therapeutic interventions, duration of admission in the inpatient ward, ICU, and patients' outcome.

Ethical considerations: The Institutional Review Boards of Faculty of Medicine, Ain Shams University approved the protocol (Approval number: FMASU R 24 / 2020). Administrative approval was obtained from PCC-ASUH. Patient consent was waived because this is a retrospective study based on medical records. The confidentiality of data was maintained by code number and used 
only for the purpose of epidemiological analysis.

\section{Data management and statistical analysis:}

Data were tabulated and statistically analyzed using SPSS, version 20 (SPSS Inc., Chicago, IL). Quantitative data were not normally distributed when tested for normality by Kolmogorov-Smirnov test. So, the data were described as median and interquartile range (IQR). Two-tailed Kruskal-Wallis test was used for comparing quantitative variables between groups. Qualitative data were expressed as frequencies (n) and percentage (\%). Chisquare and Fisher exact tests were used to test the association between qualitative variables. $\mathrm{P}$-value $\leq 0.05$ was considered significant.

\section{Results:}

During the study period, a total of 22,301 acutely poisoned patients attended PCC-ASUH ED; $1.12 \%$ of them belonged to geriatric age group ( $\geq 60$ years of age). The number of males predominated that of females in the studied sample (58.8\%). Most of the cases (64.4\%) aged between 60 and 69 years and were married $(72 \%)$. The majority of patients $(62 \%)$ came from rural areas. About $72 \%$ of them did not show any special habits of medical importance. There were around $36 \%$ of patients who had other medical comorbidities and $10.8 \%$ had psychological disorders as seen in Table 1.
The most prevalent manner of poisoning was suicidal poisoning 112 (44.8\%). Ingestion was the main route of intoxication $(n=194,77.6 \%)$. About $94 \%$ of the patients were poisoned with a single agent, while the remaining cases reported co-ingestion of more than one agent as shown in Table 1.

Food poisoning was the commonest cause of accidental intoxication, accounting for 35 cases $(34.7 \%)$, followed by animal poisoning $(n=24,23.8 \%)$. Centrally acting drugs were the most common agents responsible for suicidal poisonings, representing 39 cases (34.8\%). Antipsychotics were responsible for the most central acting drug suicidal cases $(\mathrm{n}=19,17 \%)$. Moreover, the criminal mode was only caused by centrally acting drugs (6 benzodiazepines cases). The majority of overdose substances were caused by ethanol $(52.4 \%)$, followed by synthetic cannabinoids (19\%) as presented in Table 2.

Most cases did not receive any prehospital management before presentation to PCC-ASUH $(n=203,81.2 \%)$, while 32 cases $(12.8 \%)$ received proper but incomplete management in other hospitals, clinics, or primary health care centers.

Fifteen patients $(6 \%)$ were improperly managed (e.g. induction of emesis in cases of corrosives, administration of salt and 
water as first aid management, and applying tight tourniquets in bites and stings).

The median (IQR) of delay time (time interval between exposure and arrival to PCC-ASUH) was 4 hours $(2.0-6.0)$. After admission to PCC-ASUH, specific therapeutic measures "antidotes" were used in 38 patients $(15.2 \%)$ of which atropine was the most used antidote $(n=20,52.6 \%)$, followed by scorpion and snake antivenins $(\mathrm{n}=10,26.3 \%)$. About 91 patients $(36.4 \%)$ were hospitalized for further treatment of which 51 patients $(56 \%)$ required ICU admission. The length of stay observed among admitted patients was longer in the patients admitted to ICU (median (IQR) = $2.0(2.0-4.0))$ than in those admitted to inpatient ward $($ median $(\mathrm{IQR})=1.0(1.0-$ 2.0)) as presented in Table 3.

Regarding poisoning severity score, PSS (1) was found in 131 patients (52.4\%), PSS (2) in 37 patients (14.8\%), and PSS (3) in 32 patients (12.8\%), while 43 patients (17.2\%) recorded PSS (0). Gastrointestinal manifestations predominated in the studied sample $\quad(n=112,44.8 \%)$ followed by nervous manifestations $(\mathrm{n}=94,37.6 \%)$ as shown in Table 4 . Out of the 250 cases, 7 patients (2.8\%) died showing PSS (4).

The main agents in fatal cases were insecticides/ rodenticides in 4 patients (57.1\%), followed by addiction drugs in 2 cases, and only 1 patient died as a result of other toxins (methotrexate toxicity) as shown in Table 5.

Regarding the factors affecting PSS, higher PSS was found to be significantly associated with suicidal poisoning as a poisoning manner and oral route, but it was not significantly associated with type of toxic agents. Significantly higher PSS was also observed with increased delay time until arrival to PCC-ASUH, increased length of stay in ICU, and extended total length of stay as shown in Table 5.

The presence of medical comorbidities was also significantly associated with PSS increase $(\mathrm{P}=0.003)$. However, patients' demographic factors had no significant effect on PSS such as increasing age $(\mathrm{P}=0.44)$, gender difference $(\mathrm{P}=0.76)$, residence $(\mathrm{P}=0.12)$, marital status $(\mathrm{P}=0.66)$, and special habits $(\mathrm{P}=0.07)$.

\section{Discussion:}

The present study characterizes acute poisoning in an Egyptian elderly population presented to PCC-ASUH. The most affected age group is the people ranging from 60 to 69 years, representing $64.4 \%$ of patients, showing a decline in number with increasing age.

This result is in accordance with the previous report about geriatric patients in Tehran. ${ }^{(8)}$ On the contrary, in the study conducted on geriatric patients visiting Taiwan National Poison Control Center, the 
patients aging from 75 to 85 years were $52.2 \%$ of the presented patients. ${ }^{(9)}$

The number of male patients was higher than females; this agrees with the results of Afzali et al. study. (10) However, it is contrary to other studies conducted in Egypt, Poland, and Japan where women outnumbered men. This difference may be explained by the increased liability of males to stress, addiction, and accessibility to poisoned agents compared to females. ${ }^{(11-13)}$

Although multiple studies reported that most exposures in the elderly are unintentional, (11,13) our study recognized deliberate self-harm as the most common cause of poisoning. This result is consistent with other previous studies where a higher incidence of suicide among the geriatric age group patients was reported. ${ }^{(8-10)}$

Most of our patients were married (72\%) which is similar to the findings by Khodabandeh et al. ${ }^{(14)}$ who ascertained that marital problems and economic pressures might be the principal causes of suicidal poisoning.

Various medical illnesses and psychiatric problems co-existed in the studied elderly $(36 \%$ and $10.8 \%$, respectively). Our results are slightly lower than the results reported by Kim et al. where medical and psychiatric illnesses existed in $45 \%$ and $13 \%$ of the participants, respectively. ${ }^{(15)}$ Substantially, it has been reported that chronic illnesses may play a role in the development of suicidal behaviors. ${ }^{(16)}$

The suicidal intoxication in our study was mainly caused by centrally acting drugs (antipsychotics). Older age is associated with a high rate of organic and functional brain disorders like delirium, dementia, depression, bipolar disorders, etc., and psychoactive drugs are essential for the effective management of these problems.

This could explain the tendency of the elderly to use these easily accessible agents in committing suicide as well as the fact that prescription medications are extensively used by a large proportion of the elderly due to the co-existence of multiple medical and psychiatric comorbidities. Also, the elderly are more susceptible to neurological toxicity caused by psychotherapeutic drugs. ${ }^{(6)}$

Various drugs, mainly benzodiazepines, antipsychotics, antidepressants, and cardiovascular drugs also predominated in the studies concerned with geriatric selfpoisoning in Poland and Iran. ${ }^{(12,17)}$

The accidental poisoning in our study is mostly due to food poisoning. Likely, another study reported an increase in the number of food poisoning cases, attributing this to increased consumption of refrigerated ready-to-eat foods that were 
contaminated with high levels of Listeria monocytogenes, (18) while Tagwireyi et al. stated that insecticides were the commonest agents associated with accidental exposures $(47 \%)$, followed by warfarin $(18 \%){ }^{(19)}$

Ethanol was the commonest agent involved in substance abuse, accounting for $52.4 \%$ of the examined cases, followed by synthetic cannabinoids (19\%). A national survey on drug use and health has announced that alcohol is the most abused substance among the elderly. ${ }^{(20)}$ Alcohol overdose represented $35 \%$ of the total number of toxic agents in another geriatric study. ${ }^{(21)}$

This agrees also with a previous American study which reported a steady increase in alcohol abuse among the elderly over recent years. ${ }^{(22)}$ However, opiates and opioids were the commonest agents confirmed in Afzali et al. study, constituting $81 \%$ of all abused substances (10) and also the cause of the highest PSS observed among addict Iranian poisoned patients in a comparable study. ${ }^{(8)}$

Intoxication with a single agent was seen in most of our patients which agreed with the study done by Karbakhsh and Zandi. ${ }^{(8)}$ However, Jung et al. study reported the coingestion of 2 or more drugs in $40 \%$ of the studied patients, attributing this to the existence of multiple co-morbidities for which poly-medications became available.
(23) In addition, improper use or mistaken identities due to dementia and confusion in the elderly patients may lead to increased frequency of mixed unintentional poisonings.

However, it was expected that coingestion would not significantly affect PSS of the current studied patients as most of them were NSAIDs and diuretics, considered relatively safe with no great effect on the clinical course of poisoning.

In controversy, another study found that patients with mixed poisonings suffered a more severe clinical course compared to those poisoned with a single agent, explaining this by the increased liability of elderly for drug-drug interactions due to age-related changes in pharmacokinetics and pharmacodynamics, leading to severe and even fatal clinical course. ${ }^{(24)}$

The wide range of delay time (time interval between exposure and arrival to the $P C C-A S U H$ ) in the current study (median $(\mathrm{IQR})=4.0(2.0-6.0))$ could explain the small number of patients who underwent gastric lavage. This comes in accordance with guidelines for the treatment of drug poisoning that suggest performing lavage only if the patient arrives within one hour of ingesting poison. ${ }^{(25)}$

There was a relatively longer length of stay observed among ICU admitted patients $($ median $(\mathrm{IQR})=2.0(2.0-4.0))$ compared 
to those who stayed in the inpatient ward $($ median $(\mathrm{IQR})=1.0(1.0-2.0))$ which agreed with the conclusion reported by Doak et al. who assumed that older patients require prolonged ICU stay due to poor general health and presence of comorbidities with more suspected complications. ${ }^{(26)}$

Another study attributed prolonged ICU stay to age-dependent changes in pharmacokinetics and pharmacodynamics with a subsequent prolonged course of acute poisoning in elderly patients.

Patients with severe PSS required prolonged ICU stay.

This result is nearly similar to Sacanella et al. where prolonged ICU stay is considered as a strong predictive factor of poor outcome due to age-related factors, pre-morbid status, type of toxic agent, and the need for mechanical ventilation, hemodialysis, or other interventional procedures. (28)

Regarding the poisoning severity score (PSS), PSS (1) was recorded in most of the patients $(52.4 \%)$, followed by PSS (0) in $17.2 \%$ of cases, while death occurred in $2.8 \%$ of cases. Similarly, El-Hawary et al. observed PSS (1) in $53.1 \%$ of patients, while Karbakhsh and Zandi reported PSS (2) in more than $50 \%$ of cases, with a mortality rate of $7 \% .^{(8,11)}$ On the contrary, other studies reported much higher mortality rates exceeding $9 \%$ among their studied geriatric intoxicated patients. ${ }^{(15,29)}$

Moreover, Arun et al. reported death in $40 \%$ of their patients on the first day, attributing this to the fact that toxicological mortality varies significantly and is influenced by many factors like advanced age, type of poisonous substance, compromised immunity, presence of multiple co-morbidities, and lack of social support in elderly patients. ${ }^{(30)}$

\section{Conclusion and recommendations:}

Suicidal poisoning is common in the elderly and mostly caused by antipsychotic drugs. Several variables could worsen the PSS of poisoned elderly like the manner of poisoning, presence of co-morbidities, and type of toxic agent. Further studies including several years' surveillance and additional population-based multi-centered studies should be conducted to enhance our understanding of the epidemiology of geriatric poisoning throughout Egypt.

\section{Strengths and limitations:}

The strengths of this study lie in the relatively large number of geriatric cases included in our analysis as well as the quality and consistency of the records maintained by the PCC-ASUH. Limitations include the retrospective design of the study and the data of one tertiary center (PCCASUH). 
Therefore, it might not represent the actual situation in the whole country. Also, it is expected that there was an unknown number of patients who have been successfully managed at home or in primary health care centers and thus were not included in our study.

\section{Declarations:}

- Consent for publication: "Not applicable"

- Funding: There has been no significant financial support for this work that could have influenced its outcome.

- Disclosure statement: The authors state that they have no competing interests.

- Data Availability Statement: The datasets generated and analyzed during the current study are available from the corresponding author upon request.

\section{References:}

1. Sander M, Oxlund B, Jespersen A, et al. The challenges of human population ageing. Age and ageing 2014; 44(2): 185-187.

2. Sweed HS. Population Ageing-Egypt Report. Middle East Journal of Age and Ageing 2016; 13(2): 10-17.

3. Ravindra F. The national poisons information centre in Sri Lanka: The first ten years. J Toxicol Clin Toxicol 2002; 40(5): 551-555.

4. Crump C, Sundquist K, Sundquist J, et al. Socio-demographic, psychiatric and somatic risk factors for suicide: A Swedish national cohort study. Psychol Med 2014; 44(2): 279-289.

5. Kim Y-R, Choi KH, Oh Y, et al. Elderly suicide attempters by selfpoisoning in Korea. Int Psychogeriatr 2011; 23(6): 979-85.

6. Barman B, Borab K, Nongpiurc A. Poisoning in elderly. Indian Journal of Medical Specialties 2018; 9: 113-117.

7. Junk SH, Park DY, Park JS, et al. Significance of the poisoning severity score as a prognostic factor in poisoning. J Korean Soc Emerg Med 2005; 16(6): 660-666.

8. Karbakhsh M, Zandi NS. Pattern of poisoning in the elderly: An experience from Tehran. J Clin Toxicol 2008; 46(3): 211-217.

9. $\mathrm{Hu} \mathrm{YH}, \mathrm{Chou} \mathrm{HL}, \mathrm{Lu} \mathrm{WH}$, et al. Features and prognostic factors for elderly with acute poisoning in the emergency department. Chin J Med Assoc 2010; 73(2):78-87.

10. Afzali S, Seifrabiei MA, Taheri SK, et al. Acute poisoning in Elderly; a Fiveyear study (2008-2013) in Hamadan, Iran. APJMT 2015; 4(4): 143-146.

11. El-Hawary AE, El-Mehallawi IH, ElKelany RS, et al. Pattern of acute poisoning in a sample of elderly Egyptians. Nat Sci 2019; 17(8): 79-85. 
12. Piekarska-Wijatkowska A, KobzaSindlewska K, Rogaczewska A, et al. Intentional poisoning among elderly people residents of a large urban agglomeration in Poland. Hum Exp Toxicol 2016; 35(12): 1328-1336.

13. Haoka T, Sakata N, Okamoto $\mathrm{H}$, Oshiro A, Shimizu T, Naito Y, et al. Intentional or unintentional drug poisoning in elderly people: retrospective observational study in a tertiary care hospital in Japan. Acute Med Surg 2019; 6(3): 252-258.

14. Khodabandeh F, Noorbala AA, Kahani S, et al. A Study on the Factors Associated with Attempting Suicide in Middle and Old Age Patients Referred to Loghman Hospital Poison Center in 2009. Health Psychol 2012; 11: 1-11.

15. Kim BK, Jung SY, Jung KY. Characteristics of elderly patients with acute poisoning. J Korean Soc Clin Toxicol 2010; 8(2): 61-68.

16. Bolton J, Walld R, Chateau D, et al. Risk of suicide and suicide attempts associated with physical disorders: a population-based, balancing scorematched analysis. Psychol Med 2015; 45(3): 495-504.

17. Gheshlaghi F, Salehi MJ. Suicide attempts by self-poisoning in elderly. Journal of Research in Medical Sciences 2012; 17(2): 272-275.
18. Chan YC, Wiedmann M. Physiology and genetics of Listeria monocytogenes survival and growth at cold temperatures. Crit Rev food Sci Nutri J 2009; 49(3): 237-253.

19. Tagwireyi D, Ball DE, Nhachi CF. Toxico-epidemiology in Zimbabwe: Pesticide poisoning admissions to major hospitals. Clin Toxicol 2006; 44(1): 59-66.

20. Substance Abuse and Mental Health Services Administration. Key Substance Use and Mental Health Indicators in the United States: Results from the 2018 National Survey on Drug Use and Health. (2019). Available at: https://www.samhsa.gov/data/sites/defa ult/files/cbhsq-

reports/NSDUHNationalFindingsRepor t2018/NSDUHNationalFindingsReport 2018.pdf

21. Kaeley N, Bhushan B, Subramanyam $\mathrm{V}$, et al. Clinical and demographic characteristics of geriatric patients with acute poisoning in the state of Uttarakhand J Family Med Prim Care 2019; 8 (2): 443-448.

22. Breslow RA, Castle IP, Chen CM, et al. Trends in alcohol consumption among older Americans: National Health Interview Surveys, 1997 to 2014. J Family Med Prim Care 2017; 41(5): 976-986. 
23. Jung SY, Eo EK, Kim CW, et al. Overview of poisoning admission in Korea: Based on the hospital discharge injury surveillance data. J Korean Soc Clin Toxicol 2008; 6(1): 16-24.

24. Heyerdahl F, Bjornas MA, Hovda KE, et al. Acute poisonings treated in hospitals in Oslo. A one-year prospective study(II): Clinical outcome. Clin Toxicol 2008; 46(1): 42-49.

25. Vale JA, Kulig K. American Academy of Clinical Toxicology, European Association of Poisons Centres and Clinical Toxicologists. Clin Toxicol 2004; 42(7): 933-943.

26. Doak MW, Nixon AC, Lupton DJ, et al. Self-poisoning in older adults: Patterns of drug ingestion and clinical outcomes. Age and Ageing J 2009; 38: 407-411.
27. Juurlink DN, Mamdani M, Koop A, et al. Drug-drug interactions among elderly patients hospitalized for drug toxicity. JAMA 2003; 289: 1652-1658.

28. Sacanella E, Pérez-Castejón JM, Nicolás JM, et al. Mortality in healthy elderly patients after ICU admission. Intensive Care Med 2009; 35: 550-555.

29. Zanaty AW, Elagamy SE. Retrospective study of acute poisoning in elderly cases admitted to Menoufia poisoning control center (mpcc), Menoufia university hospitals from 2012 to 2014. Egypt J. Forensic Sci. Appli. Toxicol 2016; 16(2): 113-139.

30. Arun M, Nagesh KR, Palimar V, et al. Geriatric Poisoning Fatalities: A Manipal Perspective. Medico-Legal Update 2005; 5(1):1-3. 
Table 1. Demographic features, comorbidities, and pattern of toxic agents responsible for poisoning among acutely intoxicated geriatric patients included in the study (No. $=250)$

\begin{tabular}{|c|c|c|}
\hline Demographic and clinical characteristics & No. & $\%$ \\
\hline \multicolumn{3}{|l|}{ Age groups (year) } \\
\hline - $60-69$ & 161 & 64.4 \\
\hline - $70-79$ & 63 & 25.2 \\
\hline - $80-89$ & 26 & 10.4 \\
\hline \multicolumn{3}{|l|}{ Sex } \\
\hline - Male & 147 & 58.8 \\
\hline - Female & 103 & 41.2 \\
\hline \multicolumn{3}{|l|}{ Residence } \\
\hline - Urban & 95 & 38.0 \\
\hline - Rural & 155 & 62.0 \\
\hline \multicolumn{3}{|l|}{ Marital status } \\
\hline - Single & 8 & 3.2 \\
\hline - Married & 180 & 72.0 \\
\hline - Widow & 62 & 24.8 \\
\hline \multicolumn{3}{|l|}{ Special habits } \\
\hline - Negative & 180 & 72.0 \\
\hline - Smokers & 48 & 19.2 \\
\hline - Ex-smokers & 7 & 2.8 \\
\hline $\begin{array}{l}\text { - Substance abusers (Cannabis, synthetic } \\
\text { cannabinoids, heroin, and ethanol) }\end{array}$ & 15 & 6.0 \\
\hline \multirow{2}{*}{\multicolumn{3}{|c|}{$\begin{array}{l}\text { Medical comorbidities } \\
\text { Types of medical comorbidities }\end{array}$}} \\
\hline & & \\
\hline - Cardiovascular & 22 & 24.4 \\
\hline - Cardiovascular, Diabetes Mellitus & 21 & 23.3 \\
\hline - Diabetes Mellitus & 11 & 12.2 \\
\hline - Hepatic & 9 & 10.0 \\
\hline - Respiratory & 9 & 10.0 \\
\hline - Malignancy & 5 & 5.6 \\
\hline - Stroke & 5 & 5.6 \\
\hline - Cardiovascular, renal & 4 & 4.4 \\
\hline - Diabetes Mellitus, renal & 4 & 4.4 \\
\hline Psychiatric comorbidities & 27 & 10.8 \\
\hline \multicolumn{3}{|l|}{ Manner of poisoning } \\
\hline - Suicidal & 112 & 44.8 \\
\hline - Overdose by substances of abuse & 21 & 8.4 \\
\hline - Therapeutic error & 10 & 4.0 \\
\hline - Criminal & 6 & 2.4 \\
\hline - Accidental & 101 & 40.4 \\
\hline \multicolumn{3}{|l|}{ Route of exposure } \\
\hline - Oral & 194 & 77.6 \\
\hline - Inhalation & 29 & 11.6 \\
\hline - Bite / sting & 24 & 9.6 \\
\hline - Injection & 3 & 1.2 \\
\hline \begin{tabular}{|l|} 
Co-ingestion \\
- Negative \\
- Co-ingestion with any of these drugs (as \\
NSAIDS, Diuretics, Tramadol, etc..) \\
\end{tabular} & $\begin{array}{c}235 \\
15\end{array}$ & $\begin{array}{c}94.0 \\
6\end{array}$ \\
\hline
\end{tabular}


Table 2. Types of toxic agents in relation to manner of poisoning (No.=250)

\begin{tabular}{|c|c|c|c|c|c|c|}
\hline Type of Toxic & $\begin{array}{c}\text { Total } \\
\text { (No. }=250) \\
\text { No. }(\%)\end{array}$ & $\begin{array}{c}\text { Accidental } \\
\text { (No.=101) } \\
\text { No. }(\%)\end{array}$ & $\begin{array}{c}\begin{array}{c}\text { Therapeutic } \\
\text { error } \\
(\text { No. }=10)\end{array} \\
\text { No. }(\%)\end{array}$ & \begin{tabular}{|c}
$\begin{array}{c}\text { Overdose by } \\
\text { abuse } \\
\text { substances }\end{array}$ \\
$\begin{array}{c}\text { (No.=21) } \\
\text { No. }(\%)\end{array}$ \\
\end{tabular} & $\begin{array}{c}\begin{array}{c}\text { Criminal } \\
\text { (No.=6) }\end{array} \\
\text { No. }(\%)\end{array}$ & $\begin{array}{l}\begin{array}{l}\text { Suicidal } \\
\text { (No.=112) }\end{array} \\
\text { No. }(\%)\end{array}$ \\
\hline Addiction drugs/ substances & $29(11.6)$ & $\mathbf{0}(\mathbf{0 . 0})$ & $4(40.0)$ & $21(100.0)$ & $\mathbf{0}(\mathbf{0 . 0})$ & $4(3.6)$ \\
\hline - Ethanol & $11(4.4)$ & $0(0.0)$ & $0(0.0)$ & $11(52.4)$ & $0(0.0)$ & $0(0.0)$ \\
\hline - Tramadol & $8(3.2)$ & $0(0.0)$ & $4(40.0)$ & $0(0.0)$ & $0(0.0)$ & $4(3.6)$ \\
\hline - Synthetic cannabinoids & $4(1.6)$ & $0(0.0)$ & $0(0.0)$ & $4(19.0)$ & $0(0.0)$ & $0(0.0)$ \\
\hline - Cannabis & $3(1.2)$ & $0(0.0)$ & $0(0.0)$ & $3(14.3)$ & $0(0.0)$ & $0(0.0)$ \\
\hline - Heroin & $3(1.2)$ & $0(0.0)$ & $0(0.0)$ & $3(14.3)$ & $0(0.0)$ & $0(0.0)$ \\
\hline Centrally acting drugs & $48(19.2)$ & $\mathbf{0}(\mathbf{0 . 0})$ & $3(30.0)$ & $\mathbf{0}(\mathbf{0 . 0})$ & $6(100.0)$ & 39 (34.8) \\
\hline - Antipsychotics & $19(7.6)$ & $0(0.0)$ & $0(0.0)$ & $0(0.0)$ & $0(0.0)$ & $19(17.0)$ \\
\hline - Benzodiazepines & $10(4.0)$ & $0(0.0)$ & $0(0.0)$ & $0(0.0)$ & $6(100)$ & $4(3.6)$ \\
\hline - Carbamazepine & $6(2.4)$ & $0(0.0)$ & $0(0.0)$ & $0(0.0)$ & $0(0.0)$ & $6(5.4)$ \\
\hline - Antidepressants & $5(2.0)$ & $0(0.0)$ & $0(0.0)$ & $0(0.0)$ & $0(0.0)$ & $5(4.5)$ \\
\hline - Pregabalin & $5(2.0)$ & $0(0.0)$ & $1(10.0)$ & $0(0.0)$ & $0(0.0)$ & $4(3.6)$ \\
\hline - Lithium & $3(1.2)$ & $0(0.0)$ & $2(20.0)$ & $0(0.0)$ & $0(0.0)$ & $1(0.9)$ \\
\hline Cardiovascular drugs & $18(7.2)$ & $\mathbf{0}(\mathbf{0 . 0})$ & $\mathbf{0}(\mathbf{0 . 0})$ & $\mathbf{0}(\mathbf{0 . 0})$ & $\mathbf{0}(\mathbf{0 . 0})$ & $18(16.1)$ \\
\hline Insecticides/rodenticides & $26(10.4)$ & $7(6.9)$ & $\mathbf{0}(\mathbf{0 . 0})$ & $\mathbf{0}(\mathbf{0 . 0})$ & $\mathbf{0}(\mathbf{0 . 0})$ & $19(17.0)$ \\
\hline - Organophosphates & $19(7.6)$ & $6(5.9)$ & $0(0.0)$ & $0(0.0)$ & $0(0.0)$ & $13(11.6)$ \\
\hline - Zinc Phosphide & $7(2.4)$ & $1(1.0)$ & $0(0.0)$ & $0(0.0)$ & $0(0.0)$ & $6(5.4)$ \\
\hline Household chemicals & 34 (13.6) & $22(21.8)$ & $\mathbf{0}(\mathbf{0 . 0})$ & $\mathbf{0}(\mathbf{0 . 0})$ & $\mathbf{0}(\mathbf{0 . 0})$ & $12(10.7)$ \\
\hline - Corrosives & $27(10.8)$ & $15(14.9)$ & $0(0.0)$ & $0(0.0)$ & $0(0.0)$ & $12(10.7)$ \\
\hline - Hydrocarbons & $7(2.8)$ & $7(6.9)$ & $0(0.0)$ & $0(0.0)$ & $0(0.0)$ & $0(0)$ \\
\hline Animal poisoning & $24(9.6)$ & $24(23.8)$ & $\mathbf{0}(\mathbf{0 . 0})$ & $\mathbf{0}(\mathbf{0 . 0})$ & $\mathbf{0}(\mathbf{0 . 0})$ & $\mathbf{0}(\mathbf{0 . 0})$ \\
\hline - Snake & $13(5.2)$ & $13(12.9)$ & $0(0.0)$ & $0(0.0)$ & $0(0.0)$ & $0(0.0)$ \\
\hline - Scorpion & $11(4.4)$ & $11(10.9)$ & $0(0.0)$ & $0(0.0)$ & $0(0.0)$ & $0(0.0)$ \\
\hline Food poisoning & $35(14.0)$ & $35(34.7)$ & $\mathbf{0}(\mathbf{0 . 0})$ & $\mathbf{0}(\mathbf{0 . 0})$ & $\mathbf{0}(\mathbf{0 . 0})$ & $\mathbf{0}(\mathbf{0 . 0})$ \\
\hline Carbon monoxide & $13(5.2)$ & $13(12.9)$ & $\mathbf{0}(\mathbf{0 . 0})$ & $\mathbf{0}(\mathbf{0 . 0})$ & $\mathbf{0}(\mathbf{0 . 0})$ & $\mathbf{0}(\mathbf{0 . 0})$ \\
\hline Others & $23(9.2)$ & $\mathbf{0}(\mathbf{0 . 0})$ & $3(\mathbf{3 0 . 0})$ & $\mathbf{0}(\mathbf{0 . 0})$ & $\mathbf{0}(\mathbf{0 . 0})$ & 20 (17.9) \\
\hline - Theophylline & $9(3.6)$ & $0(0.0)$ & $1(10.0)$ & $0(0.0)$ & $0(0.0)$ & $8(7.1)$ \\
\hline - Oral hypoglycemics & $6(2.4)$ & $0(0.0)$ & $0(0.0)$ & $0(0.0)$ & $0(0.0)$ & $6(5.4)$ \\
\hline - Anticoagulants & $6(2.4)$ & $0(0.0)$ & $2(20.0)$ & $0(0.0)$ & $0(0.0)$ & $4(3.6)$ \\
\hline - Diuretics & $1(0.4)$ & $0(0.0)$ & $0(0.0)$ & $0(0.0)$ & $0(0.0)$ & $1(0.9)$ \\
\hline - Methotrexate & $1(0.4)$ & $0(0.0)$ & $0(0.0)$ & $0(0.0)$ & $0(0.0)$ & $1(0.9)$ \\
\hline
\end{tabular}

Fisher exact test was used to assess the relation between manner of poisoning and major categories of toxic agents ( $\mathrm{P}$ value was $<0.001 *$ ). 
Table 3. Pre-consultation management, therapeutic measures, admission rate, and length of hospital stay in the studied geriatric patients $($ No. $=250)$

\begin{tabular}{|c|c|c|}
\hline Variables & No. & $\%$ \\
\hline $\begin{array}{l}\text { Pre-hospital Management } \\
\text { - Negative } \\
\text { - Proper incomplete } \\
\text { - Improper }\end{array}$ & $\begin{array}{c}203 \\
32 \\
15\end{array}$ & $\begin{array}{c}81.2 \\
12.8 \\
6.0\end{array}$ \\
\hline $\begin{array}{l}\text { Antidotes } \\
\text { - Negative } \\
\text { - Positive }\end{array}$ & $\begin{array}{c}212 \\
38\end{array}$ & $\begin{array}{l}84.8 \\
15.2\end{array}$ \\
\hline $\begin{array}{l}\text { Types of antidotes } \\
\text { - Atropine, Oximes } \\
\text { - Atropine } \\
\text { - Atropine, Calcium gluconate } \\
\text { - Atropine, Glucagon } \\
\text { - Atropine, blood transfusion } \\
\text { - Scorpion antivenom } \\
\text { - Snake antivenom } \\
\text { - Snake antivenom, blood transfusion } \\
\text { - Snake antivenom, blood transfusion, plasma, platelets } \\
\text { - Naloxone } \\
\text { - Hyperbaric O2 } \\
\text { - Flumazenil } \\
\text { - Folinic acid, plasma, Platelets }\end{array}$ & $\begin{array}{l}9 \\
4 \\
4 \\
2 \\
1 \\
5 \\
3 \\
1 \\
1 \\
3 \\
3 \\
1 \\
1\end{array}$ & $\begin{array}{c}23.7 \\
10.5 \\
10.5 \\
5.3 \\
2.6 \\
13.1 \\
7.9 \\
2.6 \\
2.6 \\
7.9 \\
7.9 \\
2.6 \\
2.6\end{array}$ \\
\hline $\begin{array}{l}\text { - Gastric Lavage } \\
\text { - Activated Charcoal } \\
\text { - Hemodialysis } \\
\text { - Endotracheal intubation } \\
\text { - Mechanical Ventilation }\end{array}$ & $\begin{array}{c}13 \\
103 \\
4 \\
17 \\
17\end{array}$ & $\begin{array}{c}5.2 \\
41.2 \\
1.6 \\
6.8 \\
6.8\end{array}$ \\
\hline $\begin{array}{l}\text { - Delay Time (Hour) Median (IQR) } \\
\text { - Total patients admitted to hospital } \\
\text { - Total length of stay (Days) Median (IQR) } \\
\text { - Patients admitted in inpatient ward } \\
\text { - Length of stay in inpatient (Days) Median (IQR) } \\
\text { - Patients required ICU admission } \\
\text { - Length of stay in ICU (Days) Median (IQR) }\end{array}$ & $\begin{array}{l}91 \\
40 \\
51\end{array}$ & $\begin{array}{r}4.0(2.0-6.0) \\
36.4 \\
2.0(2.0-4.0) \\
44.0 \\
1.0(1.0-2.0) \\
56.0 \\
2.0(2.0-4.0)\end{array}$ \\
\hline
\end{tabular}


Table 4. The frequency of poisoning severity score (PSS) according to the body system/function involved $($ No. $=250)$

\begin{tabular}{|l|c|c|c|c|c|c|c|c|}
\hline \multirow{2}{*}{ Body system } & \multicolumn{2}{|c|}{$\begin{array}{c}\text { PSS (0) } \\
\text { (No.= 43) }\end{array}$} & \multicolumn{2}{c|}{$\begin{array}{c}\text { PSS (1) } \\
\text { (No.= 131) }\end{array}$} & \multicolumn{2}{c|}{$\begin{array}{c}\text { PSS (2) } \\
\text { (No.= 37) }\end{array}$} & \multicolumn{2}{c|}{$\begin{array}{c}\text { PSS (3) } \\
\text { (No.= 32) }\end{array}$} \\
\cline { 2 - 9 } & No. & $\%$ & No. & \% & No. & $\%$ & No. & $\%$ \\
\hline - Gastrointestinal & 138 & 55.2 & 83 & 33.2 & 24 & 9.6 & 5 & 2.0 \\
- Respiratory & 199 & 79.6 & 26 & 10.4 & 17 & 6.8 & 8 & 3.2 \\
- Nervous & 156 & 62.4 & 59 & 23.6 & 20 & 8.0 & 15 & 6.0 \\
- Cardiovascular & 184 & 73.6 & 30 & 12.0 & 26 & 10.4 & 10 & 4.0 \\
- Muscular & 232 & 92.8 & 3 & 1.2 & 10 & 4.0 & 5 & 2.0 \\
- Metabolic & 209 & 83.6 & 21 & 8.4 & 10 & 4.0 & 10 & 4.0 \\
- Renal & 239 & 95.6 & 0 & 0.0 & 9 & 3.6 & 2 & 0.8 \\
- Hepatic & 239 & 95.6 & 4 & 1.6 & 6 & 2.4 & 1 & 0.4 \\
- Hematological & 238 & 95.2 & 1 & 0.4 & 7 & 2.8 & 4 & 1.6 \\
- Ocular effects & 247 & 98.8 & 2 & 0.8 & 1 & 0.4 & 0 & 0.0 \\
- Local effects from stings/bites & 228 & 91.2 & 13 & 5.2 & 6 & 2.4 & 3 & 1.2 \\
- Dermal & 250 & 100.0 & 0 & 0.0 & 0 & 0.0 & 0 & 0.0 \\
\hline
\end{tabular}

(PSS (0): none, no symptoms or signs related to poisoning; PSS (1): mild, transient, and spontaneously resolving symptoms or signs; PSS (2): moderate, pronounced or prolonged symptoms or signs; PSS (3): severe or life-threatening symptoms or signs; and PSS (4): fatal / death)). 
Table 5. Poisoning severity score (PSS) in relation to toxic agents and pattern of intoxication (No.= 250)

\begin{tabular}{|c|c|c|c|c|c|c|}
\hline Variables & $\begin{array}{l}\text { PSS (0) } \\
\text { No. }(\%) \\
\end{array}$ & \begin{tabular}{|l|} 
PSS (1) \\
No. $(\%)$ \\
\end{tabular} & \begin{tabular}{|l|} 
PSS (2) \\
No. $(\%)$ \\
\end{tabular} & $\begin{array}{l}\text { PSS (3) } \\
\text { No. }(\%) \\
\end{array}$ & $\begin{array}{l}\text { PSS (4) } \\
\text { No. }(\%) \\
\end{array}$ & $P$ value \\
\hline $\begin{array}{l}\text { Medical comorbidities }{ }^{\#} \\
\text { - No } \\
\text { - Yes }\end{array}$ & $\begin{array}{c}37(23.1) \\
6(6.7)\end{array}$ & $\begin{array}{l}87 \text { (54.4) } \\
44(48.9)\end{array}$ & $\begin{array}{l}20(12.5) \\
17(18.9)\end{array}$ & $\begin{array}{c}13(8.1) \\
19(21.1)\end{array}$ & $\begin{array}{l}3(1.9) \\
4(4.4)\end{array}$ & $0.003^{*}$ \\
\hline $\begin{array}{l}\text { Toxic agents }{ }^{\dagger} \\
\text { - Addiction drugs/substances } \\
\text { - Centrally acting drugs } \\
\text { - Cardiovascular drugs } \\
\text { - Insecticides/rodenticides } \\
\text { - Household chemicals } \\
\text { - Animal poisoning } \\
\text { - Food poisoning } \\
\text { - Carbon monoxide } \\
\text { - Others }\end{array}$ & $\begin{array}{c}8(18.6) \\
8(18.6) \\
6(14.0) \\
4(9.3) \\
10(23.3) \\
2(4.7) \\
0(0.0) \\
0(0.0) \\
5(11.6) \\
\end{array}$ & \begin{tabular}{|c}
$13(9.9)$ \\
$26(19.8)$ \\
$1(0.8)$ \\
$8(6.1)$ \\
$18(13.7)$ \\
$12(9.2)$ \\
$35(26.7)$ \\
$10(7.6)$ \\
$8(6.1)$ \\
\end{tabular} & $\begin{array}{c}3(8.1) \\
6(16.2) \\
5(13.5) \\
7(18.9) \\
5(13.5) \\
6(16.2) \\
0(0.0) \\
1(2.7) \\
4(10.8) \\
\end{array}$ & $\begin{array}{c}3(9.4) \\
8(25.0) \\
6(18.8) \\
3(9.4) \\
1(3.1) \\
4(12.5) \\
0(0.0) \\
2(6.2) \\
5(15.6) \\
\end{array}$ & $\begin{array}{c}2(28.6) \\
0(0.0) \\
0(0.0) \\
4(57.1) \\
0(0.0) \\
0(0.0) \\
0(0.0) \\
0(0.0) \\
1(14.3) \\
\end{array}$ & 0.854 \\
\hline $\begin{array}{l}\text { Co-ingested agents \# } \\
\text { - Negative } \\
\text { - Positive } \\
\end{array}$ & $\begin{array}{r}41(17.4) \\
2(13.3) \\
\end{array}$ & $\begin{array}{c}125(53.2) \\
6(40) \\
\end{array}$ & $\begin{array}{r}33(14) \\
4(26.7) \\
\end{array}$ & $\begin{array}{r}29(12.3) \\
3(20.0) \\
\end{array}$ & $\begin{array}{l}7(3.0) \\
0(0.0) \\
\end{array}$ & 0.508 \\
\hline $\begin{array}{l}\text { Manner of poisoning }{ }^{\dagger} \\
\text { - Accidental } \\
\text { - Therapeutic error } \\
\text { - Overdose by substances of abuse } \\
\text { - Criminal } \\
\text { - Suicidal }\end{array}$ & $\begin{array}{c}10(9.9) \\
3(30) \\
6(28.6) \\
0(0.0) \\
24(21.4) \\
\end{array}$ & \begin{tabular}{|c|}
$71(70.3)$ \\
$3(30.0)$ \\
$9(42.9)$ \\
$4(66.7)$ \\
$44(39.3)$ \\
\end{tabular} & $\begin{array}{c}12(11.9) \\
2(20.0) \\
2(9.5) \\
2(33.3) \\
19(17.0) \\
\end{array}$ & $\begin{array}{c}7(6.9) \\
2(20.0) \\
2(9.5) \\
0(0.0) \\
21(18.8) \\
\end{array}$ & $\begin{array}{l}1(1.0) \\
0(0.0) \\
2(9.5) \\
0(0.0) \\
4(3.6)\end{array}$ & $0.005^{*}$ \\
\hline $\begin{array}{l}\text { Route of Exposure }{ }^{\dagger} \\
\text { - Oral } \\
\text { - Inhalation } \\
\text { - Injection } \\
\text { - Bite } \\
\text { - Sting }\end{array}$ & $\begin{array}{c}38(19.6) \\
2(6.9) \\
1(33.3) \\
0(0.0) \\
2(18.2)\end{array}$ & $\begin{array}{c}10(54.1) \\
14(48.3) \\
0(0.0) \\
7(53.8) \\
5(45.5)\end{array}$ & $\begin{array}{c}24(12.4) \\
7(24.1) \\
0(0.0) \\
3(23.1) \\
3(27.3)\end{array}$ & $\begin{array}{c}23(11.9) \\
5(17.2) \\
0(0.0) \\
3(23.1) \\
1(9.1)\end{array}$ & $\begin{array}{c}4(2.1) \\
1(3.4) \\
2(66.7) \\
0(0.0) \\
0(0.0)\end{array}$ & $<0.001^{*}$ \\
\hline $\begin{array}{l}\text { Delay time (hour) }{ }^{!} \\
\text {Length of stay in inpatient (Days) } \\
\text { Length of stay in ICU (Days) }\end{array}$ & $\begin{array}{c}3(2-5) \\
-- \\
--\end{array}$ & $\begin{array}{l}4(3-6) \\
0(0-0) \\
0(0-0)\end{array}$ & $\begin{array}{l}4(2-5) \\
2(1-2) \\
0(0-1)\end{array}$ & $\begin{array}{l}4(2-6) \\
1(1-2) \\
3(2-4)\end{array}$ & $\begin{array}{l}2(1-6) \\
0(0-0) \\
3(2-5)\end{array}$ & $\begin{array}{c}0.044^{*} \\
0.182 \\
0.002 *\end{array}$ \\
\hline Total length of stay (Days)! & -- & $0(0-0)$ & $2(2-2)$ & $\begin{array}{c}4(3- \\
5.5)\end{array}$ & $3(2-5)$ & $<0.001 *$ \\
\hline
\end{tabular}

$(\dagger)$ Chi-square test, (\#) Fisher exact test, and (!) Kruskal-Wallis test were used; Median (IQR) was used to present quantitative data. [PSS (0): none, no symptoms or signs related to poisoning; PSS (1): mild, transient, and spontaneously resolving symptoms or signs; PSS (2): moderate, pronounced or prolonged symptoms or signs; PSS (3): severe or life-threatening symptoms or signs; and PSS (4): fatal / death)]. 


\section{الملخص العربى}

التسمم في المسنين في مركز علاج التسمم بمستثفيات جامعة عين شمس ، جمهورية مصر العربية

\section{ولاء جمعه عبد الحميد1، مها مجدى وهدان، حنان محمد عبد الوهاب3}

1 قسم الطب الثرعي و السموم الإكلينيكية بكلية الطب جامعة عين شمس.

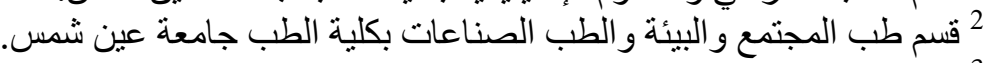

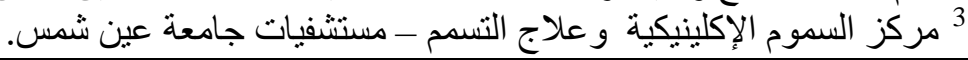

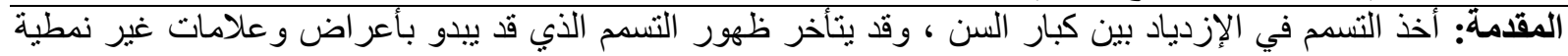

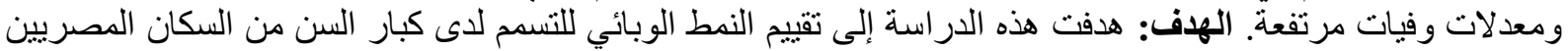

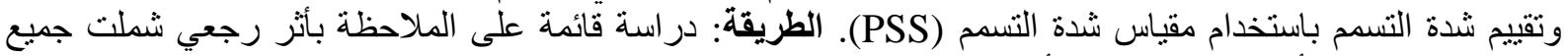

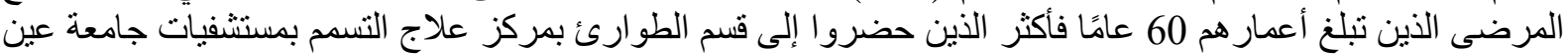

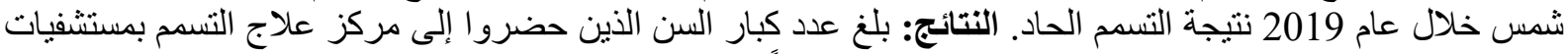

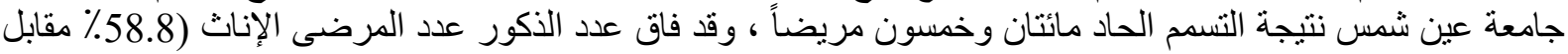

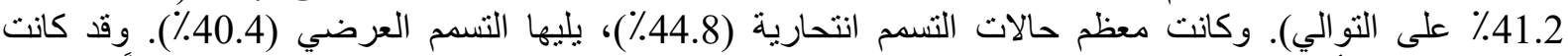

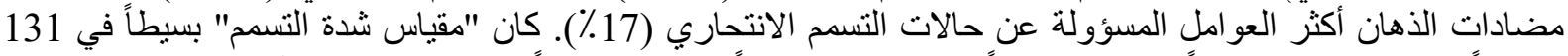

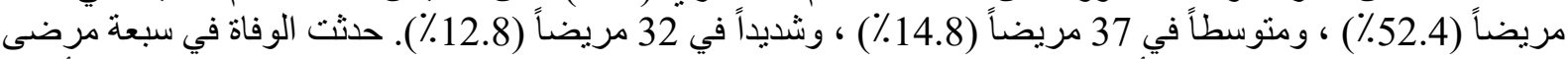

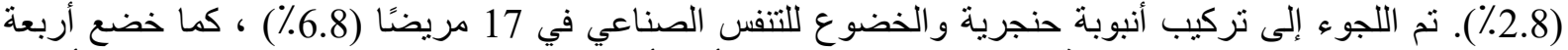

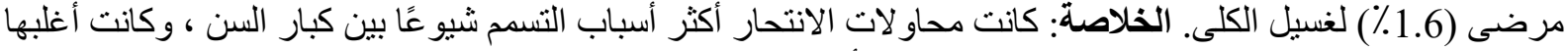

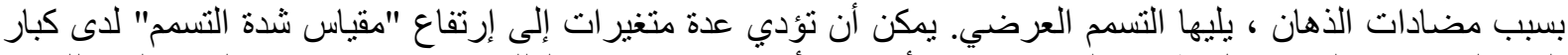

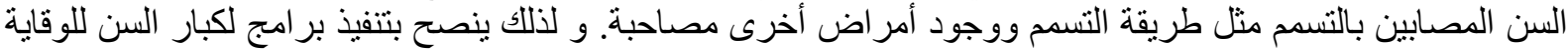
من الانتحار وكنللك التوعية العامة للحد من التسمم في هذه الفئة العمرية. 